\title{
Rearing and spawning siganids (Pisces: Teleostei) in a closed seawater system
}

\author{
H. von Westernhagen \& H. Rosenthal \\ Biologische Anstalt Helgoland (Zentrale); \\ Hamburg 50, Federal Republic of Germany
}

\begin{abstract}
KURZFASSUNG: Aufzucht und Ablaichen von Siganiden (Pisces: Teleostei) in einem geschlossenen Seewasserkreislauf. Aus den Philippinen importierte Jungfische von Siganus oramin und $S$. concatenata (S. guttatus?) wurden bei $26^{\circ} \mathrm{C}$ und $32 \% 0 \mathrm{~S}$ im geschlossenen Seewasserkreislauf mit verschiedenen kommerziellen Kunstfuttersorten (Hühnerfutter, Kaninchenfutter, Tetramin) aufgezogen und das Längen- und Gewichtswachstum über 26 Wochen verfolgt. Nach dieser Zeit wurden die ersten Tiere geschlechtsreif und durch mehrfache Hormoninjektionen (HCG) zum Abstreifen vorbereitet. Die künstliche Befruchtung der Eier gelang bei $S$, oramin mehrfach. Die Befruchtungsversuche wurden bei $12,1,15,8,20,9,30,6,32,2 \% \mathrm{~S}$ und $26^{\circ} \mathrm{C}$ durchgeführt. Zwischen 20,9 und 32,2\% $\mathrm{S}$ betrug die Befruchtungsrate $95 \%$ und darüber. Die Embryonalentwicklung und die Larvalentwicklung während der Dotterzehrung werden beschrieben.
\end{abstract}

\section{INTRODUCTION}

Although siganids are highly esteemed food fish in the tropical Indo-Pacific region (Herre \& MonTAlban, 1928) where they are widely distributed (Cuvier \& ValenCIENNES, 1835; Fowler, 1928; Munro, 1955; DAy, 1958; Marshall, 1964; SmTth, 1965; and others), there is no established fish farming of rabbitfishes in any of the South East Asian countries. The possibility of farming some species of siganids has been mentioned earlier (ABLAN \& ROSARIO, 1961), but only recently have there been serious attempts to elucidate food requirements of the herbivorous fishes (TSUDA. \& BRYAN, 1973; WeStERnHAgen, 1973 a, b, 1974 a). Although artificial fertilization of rabbitfish eggs was reported as early as 1937 by MANACOp (1937) and Fujita \& Ueno (1954), no further attempts were made to enhance controlled rearing of siganids until POPper et al. (1973) fertilized and hatched eggs from wild Siganus rivulatus and SOH \& LAM (1973) reported the induced breeding of wild catches of Siganus oramin. Latest developments on the culture of siganids have been reported by MAY et al. (1974) who succeeded in spawning wild catches of $S$. canaliculatus (S. oramin) and rearing the larvae on a diet of cultured Brachionus plicatilis and Artemia salina to metamorphosis. BeN-Tuvia et al. (1973), Tsuda et al. (1974) and WESTERNHAGEN (1974a) reared siganids in confinement and investigated their food 
habits and requirements. Recent activities in siganid research to shed some light on the biology and mariculture potentials of rabbitfishes have been summarized by LAM (1974).

Siganus oramin (S. canaliculatus) and $S$, concatenata (S. guttatus?), the species that are being dealt with in the described experiments, occur throughout the IndoPacific region. In the Philippines they are common fish on the local markets. The fishes are usually caught in traps or derived from milkfish ponds into which they have been accidentally introduced as fry by the incoming tide. On rare occasions, fishpond owners acquire siganids for stocking in ponds from local fishermen (BLANco \& VILLADOLID, 1939). Like milkfish Chanos chanos, siganids are not bred in fishponds. For future large scale culture of rabbitfishes, it is essential to develop culture and rearing methods for these potentially important fishes. Rearing rabbitfishes on artificial diet would enable fish culturists to become independent from naturally grown algae, which easily tend to get overgrazed (RANDAll, 1961; TsUda \& BRYAN, 1973), thus limiting fish production as is happening in milkfish culture unless supplementary food is given (Abagon et al. 1951; Villaluz, 1953).

\section{MATERIAL AND METHODS}

The experiments were conducted in a closed sea-water system with an approximate water capacity of 15001 . Salinity was $32.2 \%$ and temperature was maintained between $26^{\circ}$ and $30^{\circ} \mathrm{C}$. The $\mathrm{pH}$ varied from 7.7 to 8.1 and was adjusted whenever needed by the addition of a $\mathrm{NaHCO}_{3}-\mathrm{Na}_{2} \mathrm{CO}_{3}$ mixture. The waste water run off was treated in a biological sand-gravel-oyster shell grit filter supported by an ozonizer with foam skimming device. Fish tanks were either black conical troughs

Table 1

Rearing conditions in tanks supplied with water treated in the closed sea water system. Data represent mean values for the last 4 weeks prior to induced spawning. $n=$ number of observations; $\overline{\mathrm{x}}=$ mean; $s=$ standard deviation; $s \overline{\mathrm{x}}=$ error of the mean

\begin{tabular}{|ccccccc|}
\hline $\begin{array}{c}\text { Temperature } \\
(0 \mathrm{C})\end{array}$ & $\begin{array}{c}\text { Salinity } \\
(\%)\end{array}$ & $\mathrm{pH}$ & $\begin{array}{c}\mathrm{O}_{2} \\
(\mathrm{mg} / \mathrm{l})\end{array}$ & $\begin{array}{c}\mathrm{NO}_{2}-\mathrm{N} \\
(\mathrm{mg} / \mathrm{l})\end{array}$ & $\begin{array}{c}\text { Flow rate } \\
(\mathrm{l} / \mathrm{min})\end{array}$ \\
\hline $\mathrm{n}$ & 27 & 27 & 27 & 26 & 10 & 6 \\
$\overline{\mathrm{x}}$ & 25.30 & 32.06 & 7.85 & 3.81 & 0.085 & 2.027 \\
$\mathrm{~s}$ & 1.33 & 0.36 & 0.15 & 0.97 & 0.021 & 0.413 \\
$\mathrm{~s}_{\overline{\mathrm{x}}}$ & 0.26 & 0.07 & 0.03 & 0.19 & 0.007 & 0.169 \\
\hline
\end{tabular}

(capacity 851 , approximate diameter $60 \mathrm{~cm}$, height $35 \mathrm{~cm}$ ) or shallow pans $(90 \times 90 \times 18 \mathrm{~cm})$ containing about 1201 of sea-water. The flow rate through the tanks approximated $2.01 / \mathrm{min}$. Oxygen content was maintained at $70 \%$ saturation. Rearing conditions are summarized in Table 1. Illumination of the culture system was guaranteed by overhead fluorescent lights operating in a $14 \mathrm{~h}$ light-10 h dark rhythm.

The fishes had been air shipped from Manila (The Philippines). Each specimen 
was individually packed in a polythene bag, $1 / 3$ filled with sea-water $(20 \% \mathrm{~S})$ and inflated with oxygen. Of the 300 specimens dispatched, only one fish died. This was due to injuries inflicted prior to shipping.

Two species of rabbitfishes, Siganus oramin (S. canaliculatus) and S. concatenata (S. guttatus?), were introduced into the culture system. After the first day feeding with deepfrozen Enteromorpha sp., which was readily devoured by all fishes, the diet

Table 2

Main composition ( $\%$ ) of the commercial chicken and rabbit feeds used in rearing experiments, according to manufacturer (W. STRÖH jun. KG., Hobbersdorf-Lübeck, FRG). $\mathrm{IU}=$ international units

\begin{tabular}{|lcc|}
\hline \multicolumn{1}{|c}{ Composition } & Chicken feeds & Rabbit feeds \\
\hline Ground corn & 55.0 & - \\
Wheat meal & 10.7 & 12.5 \\
Wheat bran & 7.0 & 25.0 \\
Lucerne-grass meal & 7.0 & - \\
Tapioca meal & 5.0 & 15.0 \\
Fish meal & 1.0 & 3.0 \\
Ground oats & -1.0 & -1.0 \\
Bruised soja beans & 0.5 & 1.0 \\
Animal protein & 2.0 & 13.0 \\
Molasses & 2.0 & 14.0 \\
Bone meal & - & - \\
Dry fibre chips & - & 6000 \\
Corn gluten & 1.0 & 750 \\
Calcium carbonate & 6000 & \\
\hline Vitamine A (IU/kg) & 750 & \\
Vitamine D $(\mathrm{IU} / \mathrm{kg})$ & & \\
\hline
\end{tabular}

was changed to a mixture of artificial diets, which had been used in previous experiments (Westernhagen, 1974b). Commercial chicken and rabbit feeds (Table 2), admixed with a common aquarium fish food (TetraMin, 3.5\% of total dry weight of food given), were fed in $30 \mathrm{~min}$ intervals by means of an automatic feeding device for $8 \mathrm{~h} /$ day except for weekends when, for technical reasons, the fishes were given only a daily dose of TetraMin.

In the course of the experiments, it turned out to be necessary to feed a daily amount of two opened live Mytilus edulis (valve length approximately $3-5 \mathrm{~cm}$ ) to each tank containing $30-50$ fish.

\section{RESULTS}

\section{Observations during rearing experiments}

The fishes introduced into the system were divided into 6 groups, kept in separate tanks and fed different food (Table 3 ). Both species readily accepted the commercial pelleted feeds offered. The bigger pieces of ground corn found in the chicken feeds were, however, rejected. Figure 1 shows growth rates for the fishes of the different 
Table 3

Data of experimental fish at the start of the rearing experiments

\begin{tabular}{|ccccl|}
\hline Group & $\begin{array}{c}\text { Siganus } \\
\text { species }\end{array}$ & $\begin{array}{c}\text { Initial length } \\
\text { (cm) }\end{array}$ & $\begin{array}{c}\text { Initial weight } \\
\text { (g) }\end{array}$ & \multicolumn{1}{c|}{ Food } \\
\hline 1 & S. oramin & $5.0-7.0$ & $2.0-6.0$ & chicken and rabbit feeds (mixed) \\
2 & S. oramin & 4.2 & $1.0-1.5$ & chicken and rabbit feeds (mixed) \\
3 & S. oramin & 3.5 & 0.5 & dicken feeds \\
4 & S. concatenata & 4.5 & $1.5-2.0$ & dhicken feeds \\
5 & S. concatenata & 4.5 & $1.5-2.0$ & diicken and rabbit feeds (mixed) \\
6 & S. concatenata & 4.5 & $1.5-2.0$ & rabbit feeds \\
\hline
\end{tabular}

groups during the first 5 months of rearing. It appears that growth rates are dependent on the food given. Siganus concatenata grew best in the trial fed with rabbit feeds only; $S$. oramin showed better growth when fed with a mixed chicken-rabbit feeds diet rather than chicken feeds alone.

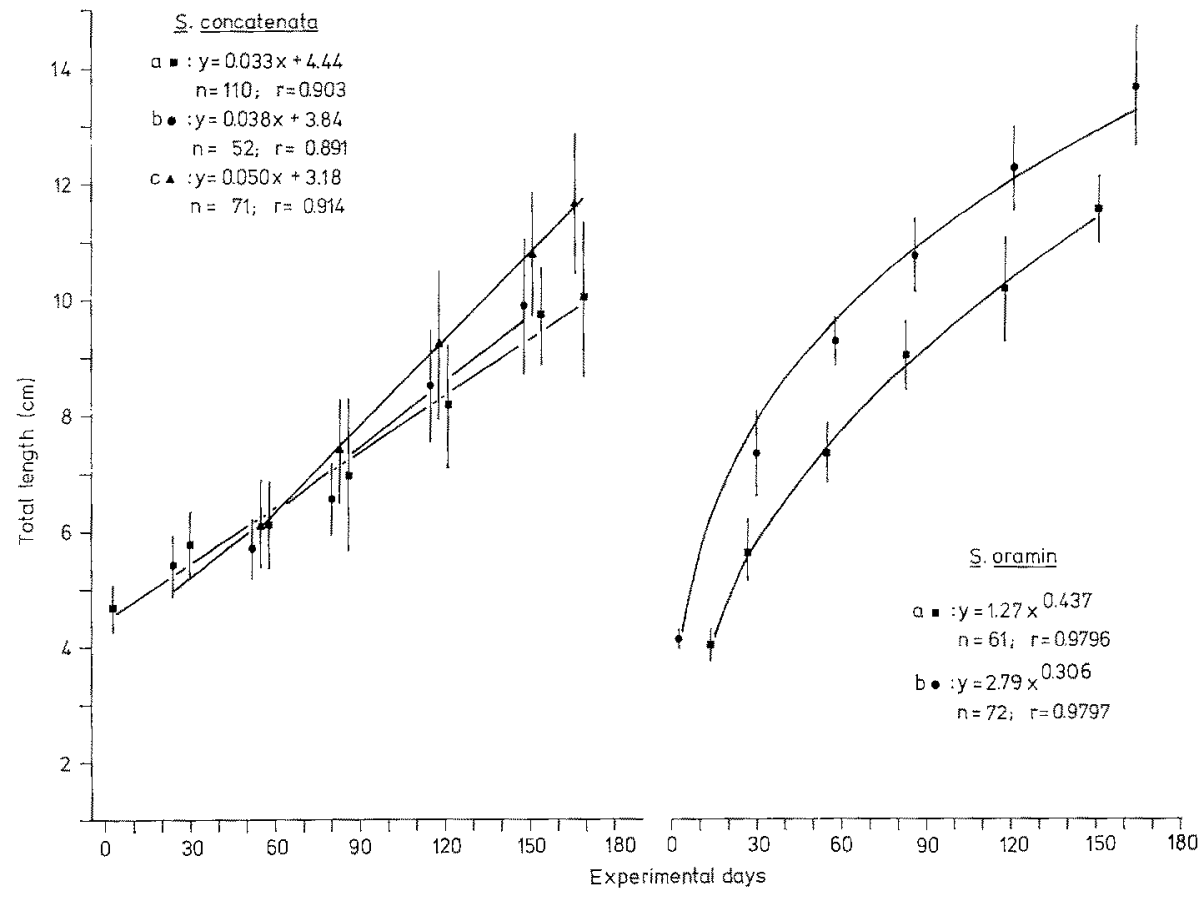

Fig. 1: Growth rates of Siganus concatenata (S. guttatus?) and S. oramin in a closed sea water system fed different artificial diets. Age of fishes at commencement of experiments approx. 4 weeks. (a) chicken feeds, (b) rabbit feeds, (c) mixed chicken and rabbit feeds. n $=$ number of measurements, $r=$ coefficient of correlation

In addition to pelleted feeds, live halved Mytilus edulis were offered. The fishes would feed voraciously on the mussels as soon as they were introduced into the tanks (Fig. 2) and clean out the valves in relatively short time. The supplementary food of fresh mussels stopped a mode of behaviour that became especially prominent in 


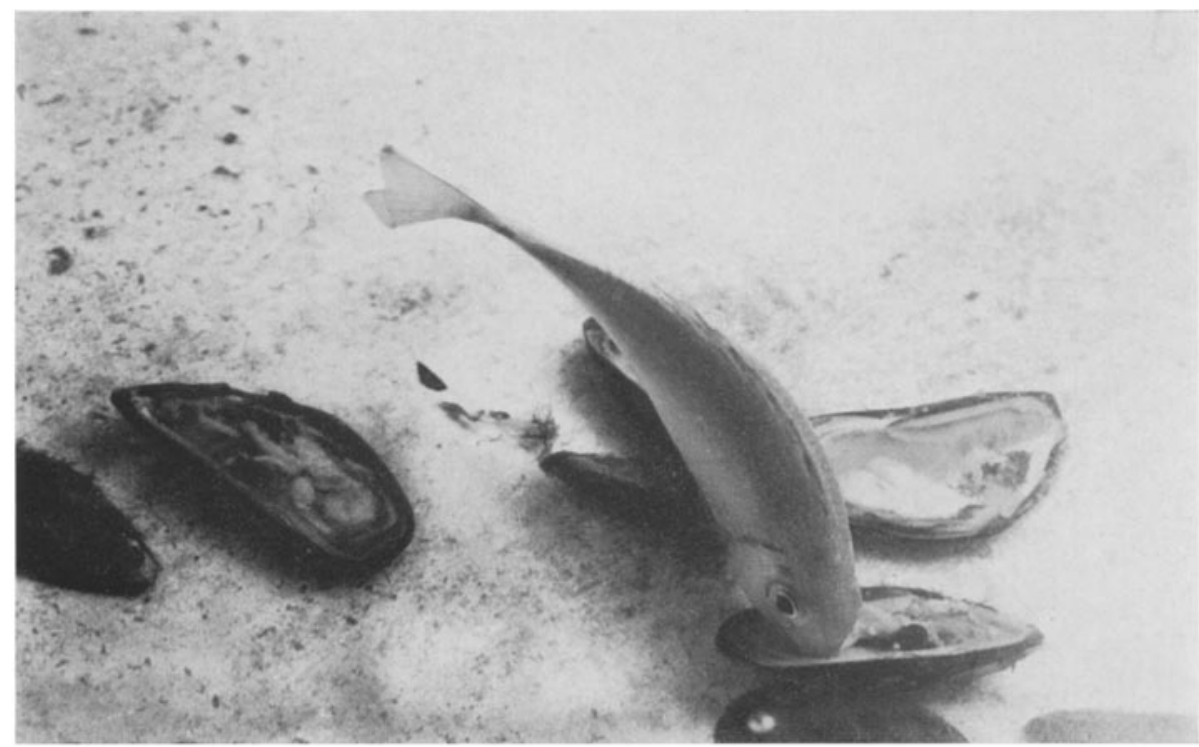

Fig. 2: Siganus oramin feeding on opened Mytilus edulis

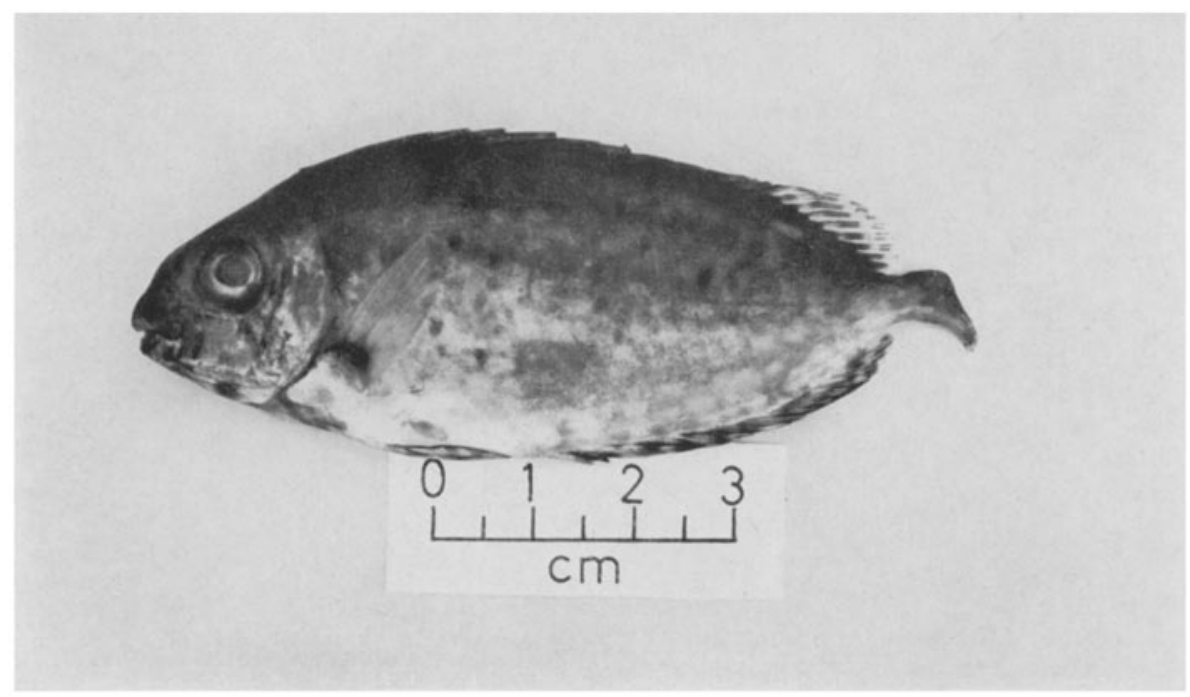

Fig. 3: Siganus oramin with caudal fin bitten (see text)

S. oramin about 8 weeks after the commencement of the rearing experiments. The fish no longer showed schooling behaviour, but instead displayed distinct territorial behaviour. Bigger individuals would bite and chase smaller specimens of the stock to the extent that in some cases caudal fins were bitten and knawed at down to the 
peduncle (Fig. 3). The wounds often became inflamed and the fishes had to be kept separate and treated with chloramphenicol for recovery.

Figure 4 shows length-weight relationship for Siganus oramin and S. concatenata grown on artificial diets. Although grown under similar conditions in the closed system there are species-specific differences in their length-weight relationsip which are expressed by the different exponents of the equations given in Figure 4. It should be

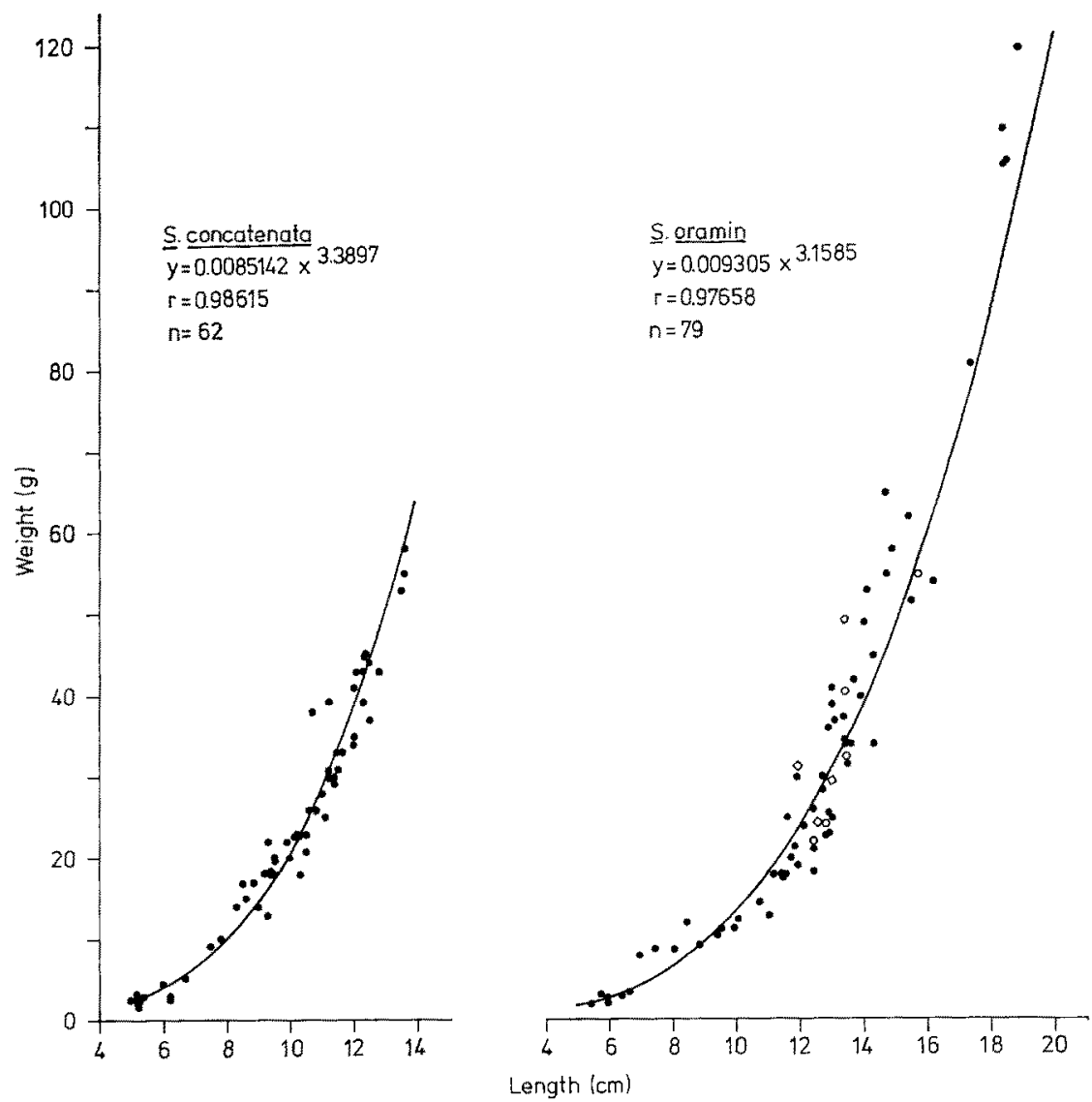

Fig. 4: Length-weight relationship of Siganus concatenata (S. guttatus?) and $S$. oramin reared under comparable conditions in a closed sea water system. $\mathrm{n}=$ number of measurements, $\mathrm{r}=$ coefficient of correlation. Symbols: - not sexed, $\bigcirc$ gravid $q+\phi, \diamond$ ripe $\delta 3$

stressed that maximum length for Siganus concatenata presented in Figure 4 is well below maximum attainable length for this species (FowLER, 1928). Since the data for the specimens used to calculate the length-weight curve are derived from immature individuals only about 6 months old, further length increase during the course of the feeding experiments can be expected.

Several specimens of Group 1 and 2 (S. oramin) became sexually mature after 
4-5 months at a length of $12.5-14.8 \mathrm{~cm}$. The females displayed distended abdomens due to the ripening of the ovaries. No natural spawning could be observed in $S$. oramin and one female died without having released its eggs. Yet some of the obviously gravid females may have spawned in the tanks spontaneously without us having noticed, since a few days before they were to be given hormone treatment, they became lean. Spawned eggs may have very well been overlooked, due to detritus accumulation on the tank bottom. During the course of the experiments ( 6 months) no external signs of sexual maturity could be detected in Siganus concatenata which were generally smaller than $S$. oramin.

In order to induce ovulation, four gravid females and four males of Siganus oramin were injected with human chorionic gonadotropin (HCG), using the dosage suggested by SoH \& LAM (1973) (0.25-0.3 IU/g body wt). All injected males but only

Table 4

Siganus oramin. Data of parental fish used for fertilization experiments

\begin{tabular}{|ccccc|}
\hline No. & Sex & $\begin{array}{c}\text { Total length } \\
(\mathrm{cm})\end{array}$ & $\begin{array}{c}\text { Body weight } \\
(\mathrm{g})\end{array}$ & $\begin{array}{c}\text { Total dosage HCG } \\
(\mathrm{I} \mathrm{U})\end{array}$ \\
\hline 1 & 9 & 14.8 & $54.8^{*}$ & 150 \\
2 & $\frac{9}{9}$ & 13.5 & $40.5^{*}$ & 150 \\
3 & $\frac{9}{8}$ & 14.8 & 55.0 & 80 \\
* spawned female & & & & \\
\hline
\end{tabular}

two treated females yielded ripe sexual products. One male and the two females were used in the following fertilization experiments (Table 4). Sperm was dispersed in a waterfilled plexiglass dish and a few minutes later the eggs were added. After 30 min, the sperm-water mixture was decanted and the incubating dishes were connected to a pump circulating the water in the dish. The sticky eggs adhered only slightly to the plexiglass (a phenomenon common also in carp eggs kept in plastic dishes; BARDACH et al., 1972), and could be easily removed for examination under the microscope. With decreasing salinity, the eggs became more and more adhesive and in the $12.1 \%$ trial they could barely be removed from the dishes without damaging them.

\section{Fertilization of stripped eggs}

Fertilization was attempted at 5 different salinities. Table 5 shows rates of fertilization obtained in the respective media. In salinities between $20.9 \%$ and $32.2 \% \mathrm{~S}$ fertilization rates were above $95 \%$, declining at $15.8 \% \mathrm{~S}$ and dropping to zero at $12.1 \% \mathrm{~S}$. Although siganid eggs have only a very narrow vitelline space, egg volume was found to depend strongly on the incubating medium, larger eggs being recorded from diluted sea-water (Table 6). This has been frequently observed in other marine fish eggs (KÄNDLER \& TAN, 1965; DeLOR, 1973). The generally spherical siganid eggs tended to become deformed after attachment on the walls of the incubating dishes. This seems to be a common feature of adhesive eggs as found by AldERDice 
Table 5

Siganus oramin. Rates ( $\%$ ) of fertilization (a) and hatching (b) of rabbit fish eggs artificially inseminated after HCG treatment

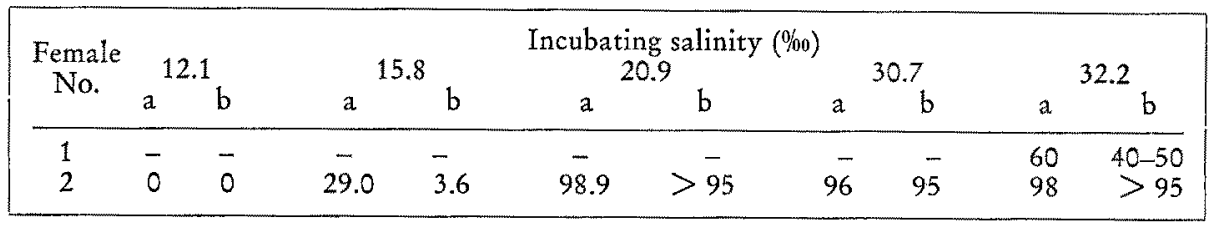

Table 6

Siganus oramin. Egg volume in relation to salinity of incubating medium. $\mathrm{n}=$ number of measurements; $\overline{\mathrm{x}}=$ mean; $s=$ standard deviation; $V=$ coefficient of variation; $\mathrm{P}=$ probability. "activated but unfertilized eggs

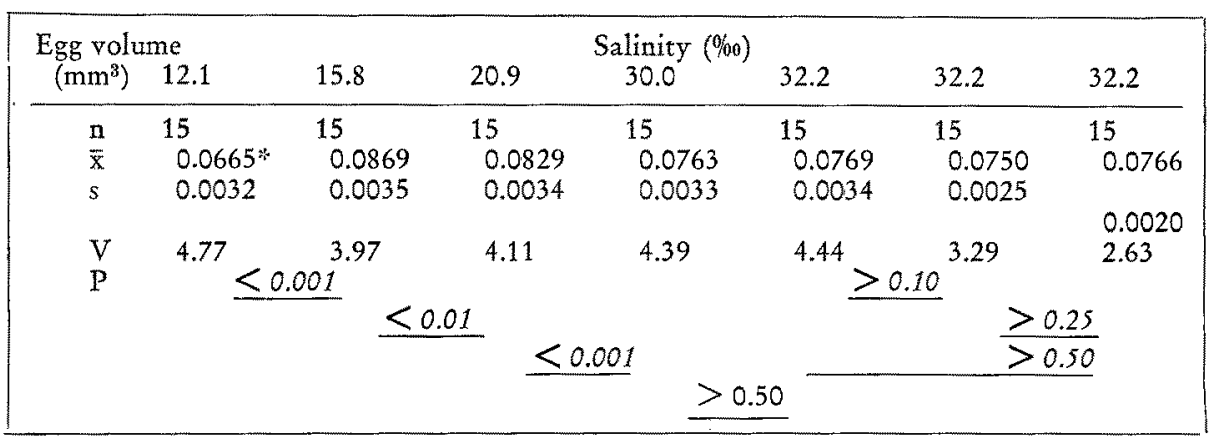

\& Rosenthal (unpublished) for eggs of the Pacific herring (Cluped pallasii). Therefore, egg volume was determined by measuring the smallest and largest diameter and calculating the volume of a rotation ellipsoid.

\section{Embryonic development}

A first brief account on embryonic development of Siganus oramin was given by SoH \& LAM (1973). From time lapse movie pictures (2 frames per min) we were able to derive proper timing figures on early ontogenesis at about $26^{\circ} \mathrm{C}$. Water uptake was completed within $18 \mathrm{~min}$ after fertilization. Separation of plasma material at the animal pole occurred between 25 and 32 min after fertilization, immediately followed by the first cleavage which was completed within $8 \mathrm{~min}$. Figure 5 indicates the duration of synchronized cleavages as well as the duration of interphases which were progressively shortened until the 256-cell stage appeared (i.g. $3 \mathrm{~h}$ after fertilization). The following cleavages were not completely synchronized. A fully grown blastodisc with maximum height occurred after about $280 \mathrm{~min}$ from fertilization. Flattening of the blastodisc began at $5 \mathrm{~h}$ after fertilization, followed by the germ ring stage, which indicated the beginning of epiboly and started about $6.5 \mathrm{~h}$ after fertilization. $50 \%$ yolk overgrowth was completed after $7.5 \mathrm{~h}$ of development. Starting at this stage, 
Rearing and spawning siganids

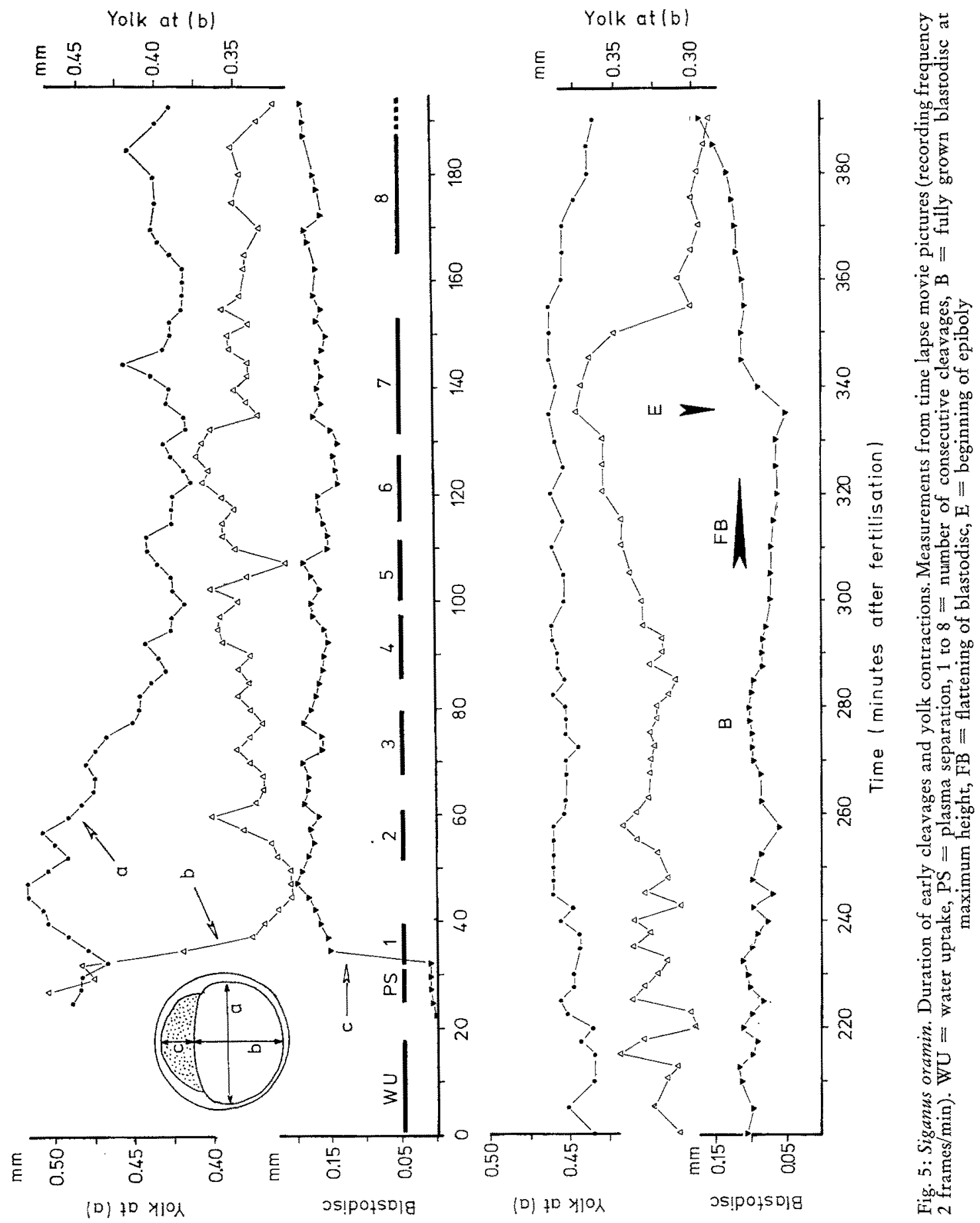


progress in epiboly slowed down somewhat reaching $70 \%$ overgrowth after $8.5 \mathrm{~h}$, and $85 \%$ after $9 \mathrm{~h}$.

During early development, "yolk contractions" could be observed. These phenomena believed to be caused by contractions of the periblast (KOPSCH, 1901; OpPENHEIMER, 1936; WÜLKER, 1964), were to some extent synchronized with the occurrence of cleavage. They appeared to be more irregular than those described for other fishes (e. g. Esox, Salmo sp.; WülKER, 1964). From time lapse movie picture analyses the small but measurable changes in yolk diameter were quantified. The yolk diameter at axis a (see insert Fig. 5) decreased drastically during the course of the first four cleavages, thereafter remaining at a fairly constant diameter interrupted only by short-lasting expansions just prior to or during each subsequent cleavage. These changes in diameter continued to occur until after the eighth cleavage. Oscillating alterations in diameter $b$ were such that diameter $b$ always expanded when diameter $a$ was shortened and vice versa. After the eighth cleavage, yolk diameter at axis $a$ and $b$ tended to remain constant until the commencement of epiboly, when the yolk started to bulge into the blastodisc.

Our observation on organo-differentiation are in good agreement with descriptions given by SoH \& LAM (1973). As in herring embryos (K'UPFFer, 1878), only one Kupffer's vesicle appeared (about $16 \mathrm{~h}$ after fertilization). Secondary vesicles, described for other fish species (NoRDaHL, 1970; Rosenthal \& Fonds, 1973) have not been observed in our experiments. Incubation time was determined to last between 27 and $29 \mathrm{~h}$ in all salinities tested. Figure 6 shows appearance and developmental stages of Siganus oramin eggs incubated at $32.2 \% 00 \mathrm{~S}$ in running sea water of the closed system. Due to additional aeration, oxygen content in the incubating medium was maintained at $6.2 \mathrm{mg} / 1$.

As shown by SoH \& LAM (1973), the eggs of $S$. oramin contain several oil globules. Due to fusion the number of these globules diminishes during ontogenesis. At the 16-cell stage all eggs contained more than four droplets (Fig. 7) whereas at the early blastodisc stage, $4 \mathrm{~h}$ after fertilization, only $92.5 \%$ of the eggs contained more than 4 droplets. $24 \mathrm{~h}$ after fertilization, $30 \%$ of the observed eggs showed 1 oil globule only (Table 7).

During the course of embryogenesis the diameter of the largest oil globule increased due to fusion with other oil droplets (Table 7). All droplets performed irregu-

Table 7

Siganus oramin. Percentages of eggs with different numbers of oil droplets and the size of the first and second largest oil droplet in relation to incubation time. $\mathrm{n}=$ number of observations; $\overline{\mathrm{x}}=$ mean; $\mathrm{s}=$ standard deviation; rearing temperature $26-27^{\circ} \mathrm{C}$, salinity $32.2 \%$

\begin{tabular}{|c|c|c|c|c|c|c|c|c|}
\hline \multirow{3}{*}{$\begin{array}{l}\text { Hours after } \\
\text { fertilization }\end{array}$} & \multirow{2}{*}{\multicolumn{5}{|c|}{$\begin{array}{c}\text { Percentages of eggs containing } \\
\text { oil droplets } \\
\text { number of droplets }\end{array}$}} & \multicolumn{3}{|c|}{ Diameter of oil droplets (mm) } \\
\hline & & & & & & & & rgest \\
\hline & 1 & 2 & 3 & 4 & $>4$ & $\mathrm{n}$ & $\mathrm{s}$ & s \\
\hline 2 & 0 & 0 & 0 & 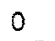 & 100 & 32 & $9 \pm 0.015$ & $0.1025 \pm 0.013$ \\
\hline 4 & 0 & 0 & 0 & 7.5 & 92 & & \pm 0.014 & 0.014 \\
\hline 24 & 30 & 62 & 6 & 2 & 0 & 50 & $0.1840 \pm 0.014$ & $0.1220 \pm 0.029$ \\
\hline
\end{tabular}




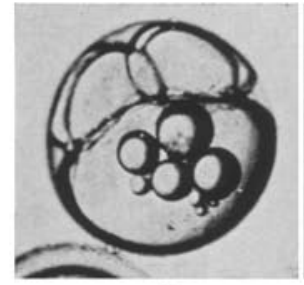

a

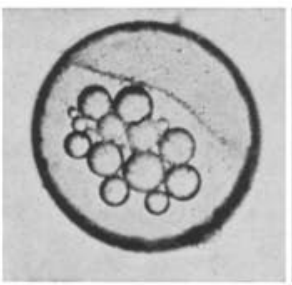

d

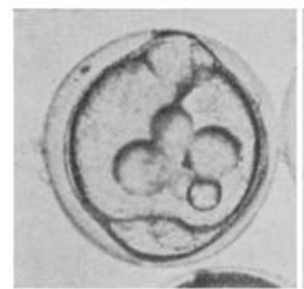

g

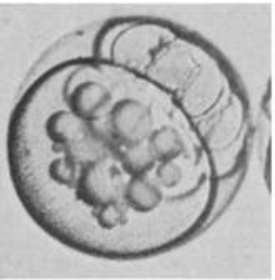

b

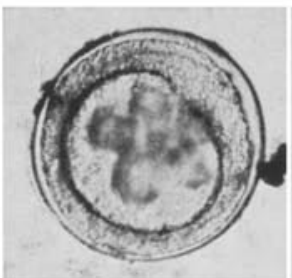

e

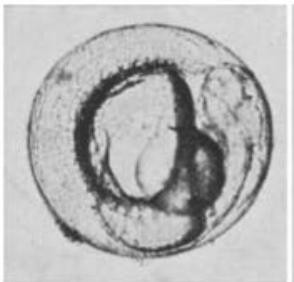

$\mathrm{h}$

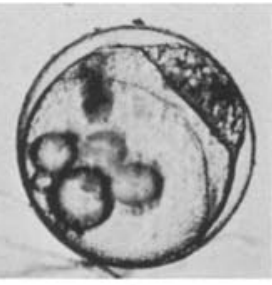

C

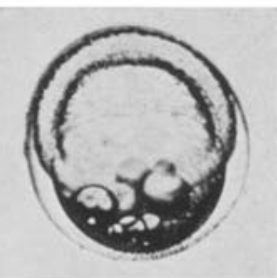

f

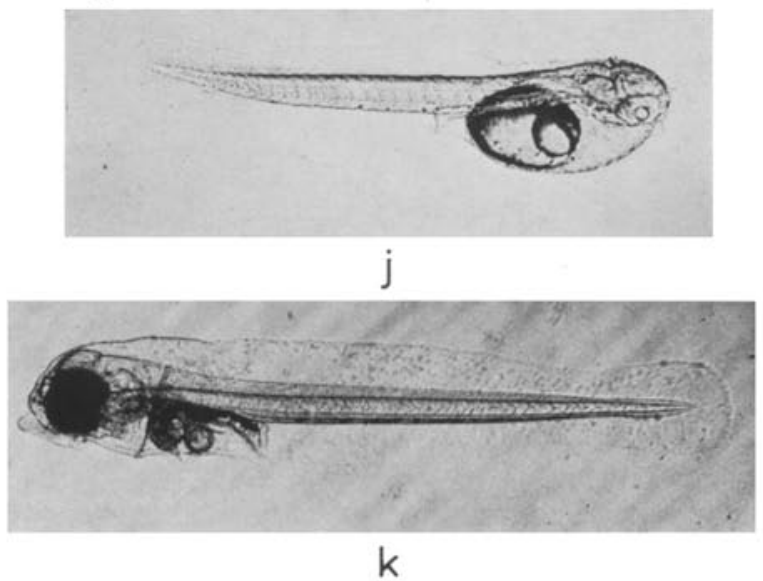

Fig. 6: Siganus oramin. Embryonic and early larval stages of artificially inseminated eggs after HCG treatment of parental fish. Incubating conditions: $32.2 \% \mathrm{~S}, 26-28^{\circ} \mathrm{C}$. (a) 4 cell stage, (b) 16 cell stage, (c) early blastodisc, (d) flattening of blastodisc just prior to gastrulation, (e) early gastrula, (f) more than $50 \%$ yolk overgrowth (epiboly), (g) neurulation, (h) embryo forming full circle, (i) prior to hatching, (j) newly hatched yolk sac larva, (k) larva $48 \mathrm{~h}$ after hatching 
lar movements on the yolk surface changing their positions at every cleavage as well as during the "contractions" of the yolk. During progressing epiboly, they were forced towards the generative pole. It was only at this stage that the globules started to fuse. Aside from the above described movements, oil globules were spinning around their own axis independently from other oil droplets and in different directions at irregular time intervals.

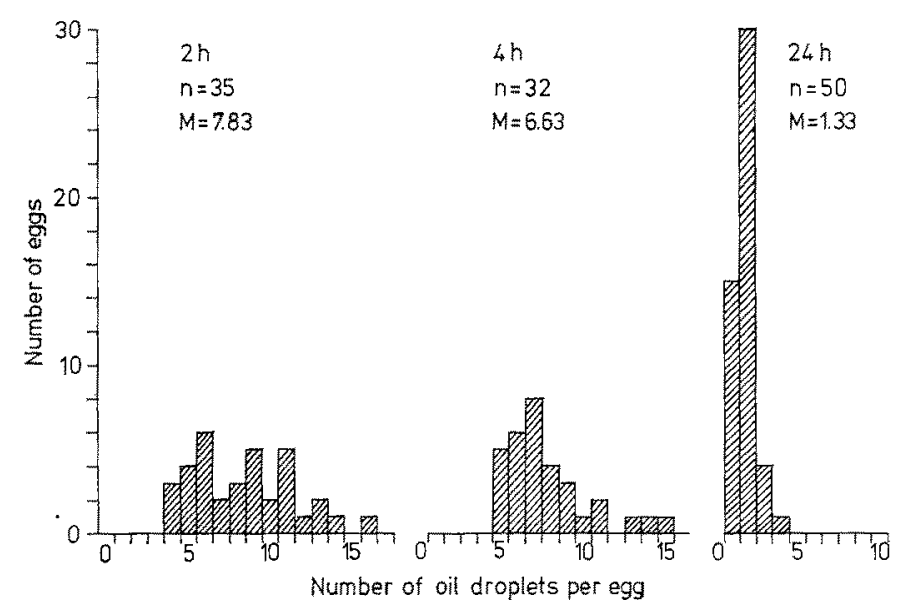

Fig. 7: Number of oil globules in eggs: 2,4 and $24 \mathrm{~h}$ after fertilization. Incubating temperature approximately $26^{\circ} \mathrm{C}$, salinity $32.2 \% \mathrm{n}=$ number of observed eggs, $\mathrm{M}=$ median

\section{Larval characteristics at hatching and during yolk absorption}

Process of hatching in the incubators was finished within a relatively short period. $50 \%$ hatching was noted between 0.5 and $2.0 \mathrm{~h}$ after the first larva had appeared. The larvae hatched at an ontogenetically early stage (Fig. 6j). Hatching success in the trials from 20.9 to $32.2 \% \mathrm{~S}$ equalled or surpassed $95 \%$, but was only $3.6 \%$ at $15.8 \% \mathrm{~S}$, where no viable larvae occurred (Table 5). Total length of larvae at hatching was around $2 \mathrm{~mm}$. Slightly but significantly larger larvae were found in the lower salinity $(20.9 \%$, Table 8$)$. After 2 days, larvae at $20.9 \%$ S showed significantly less length increment than specimens from the high salinity trial. Yolk absorption appeared to be different in high and low salinities. Within $24 \mathrm{~h}$ of hatching about $70 \%$ in $20.9 \% \mathrm{~S}$, $64 \%$ in $30.6 \% 0 \mathrm{~S}$ and $59.4 \%$ in $32.2 \% \mathrm{~S}$ of the initial yolk volume were utilized. In $15.8 \% \mathrm{~S}$ yolk sacs ruptured shortly after hatching due to excess water uptake and larvae died shortly after, a phenomenon described by WESTERNHAGEN (1970) for flounder (Pleuronectes flesus) larvae hatched in low salinity water.

Size of otic capsules at hatching was related to the incubation salinity, but existing differences diminished during yolk absorption (Table 9). Eye diameter was not found to be influenced by the salinity of the incubation medium. 
Table 8

Siganus oramin. Total length of larvae (mm) at hatching and during yolk absorption at different salinities. $\mathrm{n}=$ number of measurements; $\tilde{\mathrm{x}}=$ mean; $\mathrm{s}=$ standard deviation; $\mathrm{V}=$ coefficient of variation; $\mathrm{P}=$ probability

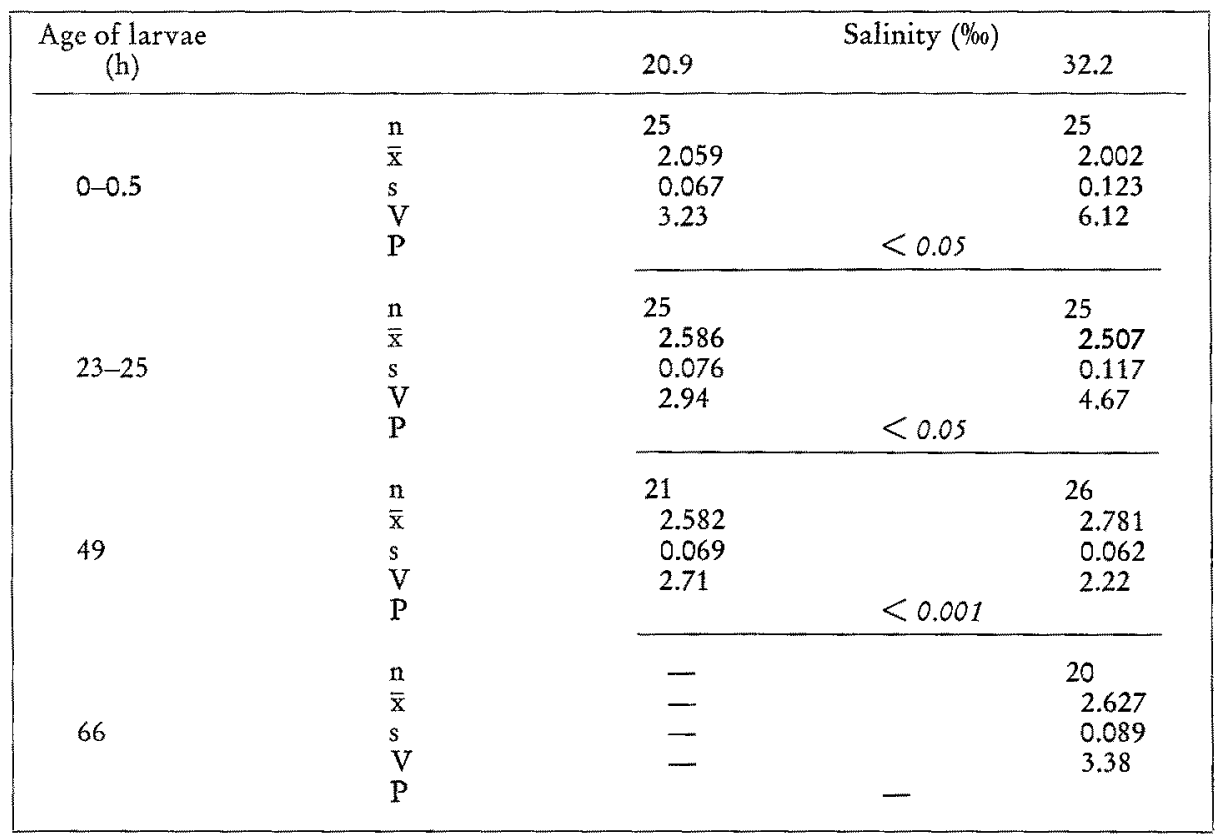

Table 9

Siganus oramin larvae. Diameter of otic capsules and eyes of newly hatched larvae kept in different salinities during yolk absorption

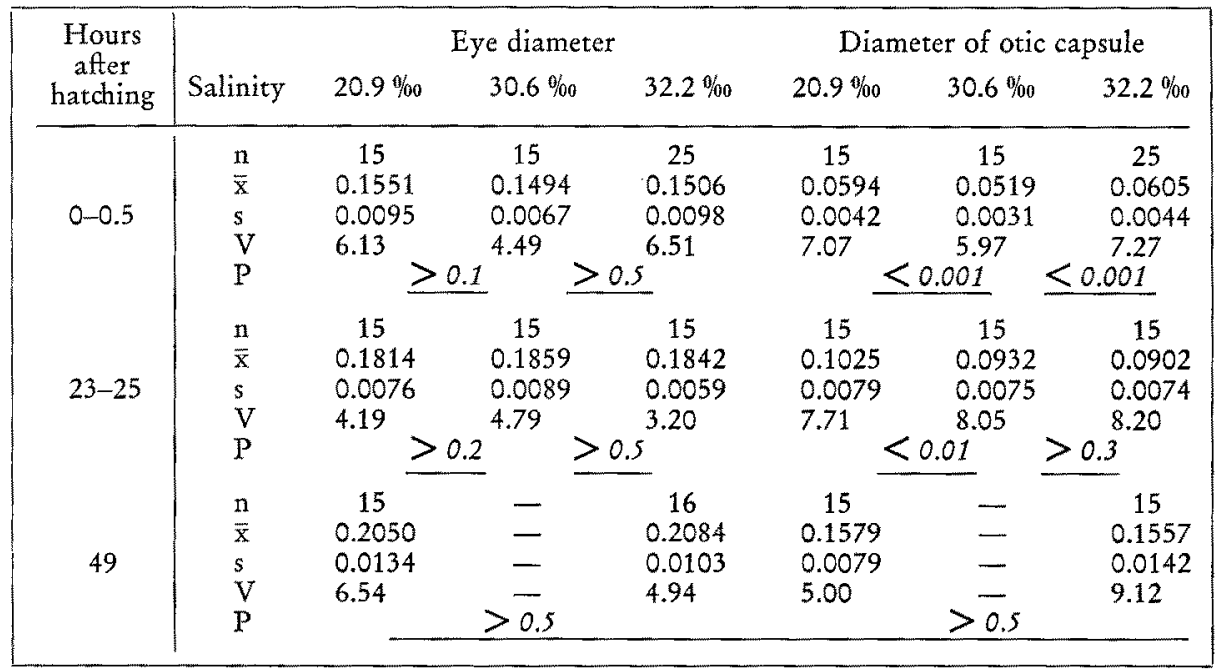


In all salinities, except for $15.8 \%$, newly hatched larvae were very active, performing jerking swimming movements towards the surface, seldom lying at the bottom of the incubating jars as described by SoH \& LAM (1973).

Sinking velocity of larvae strongly depended on the salinity of the surrounding water. At $32.2 \% \mathrm{~S}$ the larvae maintained almost neutral buoyancy, while at $20.9 \% \mathrm{~S}$ sinking velocity approximated $0.5-1.0 \mathrm{~cm} / \mathrm{sec}$. During phases of inactivity, larvae in the low salinity trial turned readily head down, while the almost buoyant larvae in natural sea water maintained many differing positions.

$48 \mathrm{~h}$ after hatching the larvae had functional jaws (mean dental length $0.24 \mathrm{~mm}$ ) and pectoral fins, and displayed food searching behaviour. By this time the yolk was almost absorbed and there was only a small oil globule left (Fig. 6k).

Table 10

Siganus oramin. Percentages of larvae with different numbers of oil globules and size of first and second largest oil droplet in relation to salinity and time after hatching. $\mathrm{n}=$ number of observations; $\overline{\mathrm{x}}=$ mean; $\mathrm{s}=$ standard deviation; rearing temperature $26^{\circ}-27^{\circ} \mathrm{C}$

\begin{tabular}{|c|c|c|c|c|c|c|c|}
\hline \multirow{3}{*}{$\begin{array}{c}\text { Rearing } \\
\text { salinity } \\
(\% 0)\end{array}$} & \multirow{3}{*}{$\begin{array}{l}\text { Age of } \\
\text { larvae } \\
\text { (h) }\end{array}$} & \multirow{3}{*}{\multicolumn{2}{|c|}{$\begin{array}{l}\text { Percentages } \\
\text { of larvae with } \\
\text { one and two } \\
\text { oil droplets in the } \\
\text { yolk }\end{array}$}} & \multicolumn{4}{|c|}{ Diameter of oil droplets (mm) } \\
\hline & & & & \multicolumn{2}{|c|}{ largest oil droplet } & \multicolumn{2}{|c|}{ second largest droplet } \\
\hline & & & & $\mathrm{n}$ & $\bar{x}$ & $\mathrm{n}$ & $\overline{\mathrm{x}}$ \\
\hline \multirow[t]{2}{*}{20.9} & 0.5 & 88 & 12 & 25 & $0.1771 \pm 0.009$ & 8 & $0.0868 \pm 0.0270$ \\
\hline & 24.0 & 100 & 0 & 25 & $0.1400 \pm 0.011$ & - & - \\
\hline \multirow[t]{2}{*}{30.6} & 1.0 & 72 & 28 & 25 & $0.1737 \pm 0.010$ & 7 & $0.1020 \pm 0.0197$ \\
\hline & 26.0 & 100 & 0 & 15 & $0.1473 \pm 0.009$ & - & - \\
\hline \multirow[t]{3}{*}{32.2} & 0.5 & 84 & 16 & 25 & $0.1703 \pm 0.015$ & 7 & $0.1029 \pm 0.0173$ \\
\hline & 24.5 & 100 & 0 & 15 & $0.1450 \div 0.008$ & - & - \\
\hline & 27.5 & 100 & 0 & 15 & $0.098 \pm 0.009$ & - & - \\
\hline
\end{tabular}

Table 10 presents number and size of oil globules found in newly hatched and approximately one day old larvae reared at three different salinities. In all salinities, the majority of the newly hatched larvae observed contained one, while 12 to $28 \%$ harboured two oil droplets. $24 \mathrm{~h}$ after hatching, all specimens examined had one droplet only. Although not indicated in Table 10, occasional specimens taken from the hatching jars contained more than two oil globules. The initial size of the largest oil droplet at hatching was significantly larger in low salinities than in natural sea water $(P<0.05)$, decreasing continously with advancing yolk absorption. Similar findings were reported by MAY (1974) for larvae of Bairdiella icistia.

After two days $90 \%$ of the larvae in $20.9 \%$ water had died but there was no mortality at 30.1 and $32.2 \% \mathrm{~S}$. In the latter trials, all larvae survived for at least three days befor they started to die from starvation. First experiments to raise larvae on an artificial diet failed due to ladk of adequate food and feeders. 


\section{DISCUSSION}

Our results prove that siganids can be reared in captivity on artificial diet from juvenile to mature specimens in a relatively short time.

Assuming that the fishes when introduced into the rearing tanks were about one to two months old, it took only 6-7 months for them to reach maturity and produce eggs. Similar data were obtained by Tsuda et al. (1974), who raised Siganus canaliculatus on a mixed trout chow-Enteromorpha diet. Although the stage of maturity of their experimental fish was not stated, it can be seen from the growth curve that the fishes apparently reached maturity after about 35 weeks. In agreement with these and our data, LaM (1974) mentioned that "In fact, we have evidence to indicate that $S$. canaliculatus can mature in captivity earlier than in nature".

Artificial feeds are advantageous as they are available throughout the year. The culturist does not depend on algal growth in ponds or similar food stuff which might be difficult to secure. Rearing siganids on artificial diets would also eliminate the possible danger of ciguatera poisoning as pointed out by HERzBERG (1973) for Siganus luridus of the Mediterranean coast of Israel.

As shown by previous research (BEN-Tuvia et al., 1973; Tsuda et al., 1974; WeSTERNHAgEN, 1974b), juvenile and adult siganids, although naturally herbivorous, feed on a variety of food stuff when reared in captivity. In fact, Tsuda et al. (1974) found that Siganus canaliculatus grew much better on a trout chow-Enteromorpha diet than on Enteromorpha sp. alone. Thus in captivity, when fed an artificial diet, the fishes seem to be less fastidious compared to occasions when different algae species abound. In feeding experiments conducted earlier (WESTERNHAGEN, 1974a), minced Modiolus sp. were rejected by siganids that were exclusively fed on a surplus of red and green algae. In this context, LAM (1974) has stated that siganids, which are herbivorous in nature, will become omnivorous in captivity.

A main drawback and obstacle for the successful future large scale culture of Siganus oramin appears to be the small size at which the fishes reach maturity (Table 3 ). Females in our experiments reached maturity at a length of about $13.5 \mathrm{~cm}$ and weighed around $50 \mathrm{~g}$. Mature wild catches of Siganus oramin have been reported by MaNacop (1937) and Westernhagen (1973) to be only small. 11-15 cm were recorded for males and 13-21 cm for females. Herre \& Montalban (1928) mentioned that the largest specimen they examined was a $21.8 \mathrm{~cm}$ long female. Marshall (1964) indicated a maximum length of $25 \mathrm{~cm}$ for this species in Australia.

In our experiment the largest gravid female encountered measured only $15.8 \mathrm{~cm}$ $(55 \mathrm{~g})$. The data obtained by LAM (1974) generally agree with the above mentioned figures. The small size of the mature fishes is a decidedly negative characteristic since, as LAM (1974) mentioned, the fishes might die after spawning, thus having reached their final size at maturity. In our experiments spawned parental fish died after a few days, after developing lesions of the skin at the abdomen. We assume that death was probably caused by rough handling during stripping.

Not all fishes in the system became gravid upon reaching a length of around $14 \mathrm{~cm}$ (Fig. 1). There were still a few (probably female) specimens, measuring from 18.5 till $19.0 \mathrm{~cm}$ and weighing $105-120 \mathrm{~g}$, that were not yet gravid. The fishes still displayed voracious feeding whenever food was offered. LAM (1974) also reported the occasional 
occurrence of siganids as heavy as $180 \mathrm{~g}$. Munro (1955) and SMITH (1965) even indicated the maximum length of Siganus oramin with $35 \mathrm{~cm}$. Our own observations on fish markets in The Philippines confirm that there are specimens of $S$. oramin reaching $25 \mathrm{~cm}$ and more in length. Thus selective breeding could be a means to eliminate unwanted small growth from culture stodks.

Siganus concatenata ( $S$, guttatus?), the other species reared, appears to be slower growing than $S$. oramin (Fig. 1). Although the laboratory specimens reached about $12 \mathrm{~cm}$ in length (Fig. 2), the fishes did not then show any external signs of maturity. Data for maximum length of $S$. concatenata given by FowLER (1928) and HeRRE \& Montalban (1928) are similar to those given for $S$. oramin and there is no reason to believe that $S$. concatenata should grow larger than $S$. oramin. The attainable maximum weight might possibly be higher in $S$. concatenata because this species has a relatively deeper body than $S$. oramin, as is evident from Figure 4. Specimens of Siganus concatenata of a mean total length of $12 \mathrm{~cm}(14 \mathrm{~cm})$ averaged $40 \mathrm{~g}(67 \mathrm{~g})$ in weight while $S$. oramin individuals of the same size weighed only $25 \mathrm{~g}(37 \mathrm{~g})$.

From the results of the incubating trials, it is evident that the optimum salinity for hatching and rearing larval siganids is around $32 \%$. Larval survival was best in this salinity range. Larvae lived generally one day longer in $32 \% \mathrm{~S}$ than in the $20.9 \% \mathrm{~S}$ trial, where $90 \%$ of the specimens died prior to complete yolk absorption. This indicated that although low salinities $(20.9 \%$ might suffice for successful incubation, they are definitely not favourable for larval growth and rearing. The successful rearing experiments with larvae of Siganus canaliculatus reported by MAY et al. (1974) have been conducted from 30.5 to $33.8 \%$ S. Possibly as a result of higher energy requirements due to decreased buoyancy in the lower salinity trail, larval growth was retarded compared to length increment of larvae kept in natural sea water (Table 8). This deduction is also supported by the data of yolk absorption rates of larvae living in different salinities. Highest absorption rates within 24 hrs after hatching were recorded in $20.9 \% \mathrm{~S}(70 \%)$ whereas in $32.2 \%$ only $59.4 \%$ of the initial yolk volume were utilized. Although in their natural habitat juvenile siganids are usually caught close to beaches, in bays or even in river estuaries with low salinities (BLANCO \& VILLADOLID, 1939), eggs must be deposited further offshore in order to ensure high larval survival. It is probably after metamorphosis that, because of their feeding on benthic algae, rabbitfish fry invade shallow near shore and estuarine waters. During several night catches on siganid fry with beach seines in The Philippines we have never caught any siganids larger than $6 \mathrm{~cm}$ ( $1 \%$ of the total siganid catch) in shallow bays which are usually rich in rabbitfish fry $(22-28 \mathrm{~mm})$. Individuals measuring $4-10 \mathrm{~cm}$ were always abundant in the littoral zone $(50-200 \mathrm{~cm}$ depth). Large specimens of $25-30 \mathrm{~cm}$ were only encountered scubadiving at the drop of the fringing reefs, $20-30 \mathrm{~m}$ deep. Thus the reason that obviously mature specimens did not spawn spontaneously in our sea-water system might be partially due to the spawners' requirement of water deeper than offered in our rearing tanks $(15 \mathrm{~cm}$ water depth)*

* After the completion of the above described experiments several specimens of $S$. aramin became gravid and male and female sexual products were obtained without the help of HCG injections. Spontaneous spawning of mature individuals in the rearing tanks could also be observed. 


\section{SUMMARY}

1. Two species of siganids from The Philippines, Siganus oramin and S. concatenata (S. guttatus?), were reared in a closed sea water system and fed different artificial feeds.

2. A comparison between commercial chicken and rabbit feeds in regard to their suitability as siganid feeds led to the conclusion that for this purpose the latter was the more appropriate diet.

3. Within six months juvenile $S$, oramin $(4-6 \mathrm{~cm}, 2-6 \mathrm{~g})$ reached maturity and were treated with human chorionic hormone (HCG) in order to induce ovulation.

4. Two females were successfully stripped after having received HCG injections. The eggs were artificially inseminated and incubated at 15.8, 20.9, 30.6 and $32.2 \% \mathrm{~S}$.

5. Early embryogenesis was evaluated by means of time lapse movie pictures (two frames/min).

6. Incubation of the eggs at $26^{\circ}-28^{\circ} \mathrm{C}$ took $29 \mathrm{~h}$ from fertilization to hatching. Viable larvae hatched only between 20.9 and $32.2 \% \mathrm{~S}$ and larval survival was best in $32.2 \% \mathrm{~S}$. There was no viable hatch at $15.8 \% \mathrm{~S}$, and no fertilization occurred at $12.1 \% \mathrm{~S}$.

Acknowledgements. We are indebted to G. Fürstenderg and J. Kinnckmann for expert technical assistance and M. BLAKE for advice on the preparation of the manuscript.

\section{LITERATURE CITED}

Al?agon, M. A., Bunag, D. M. \& de Vera, A. M., 1951. "Gulaman dagat" as supplementary feed for bangos. Bull. Fish. Soc. Philipp. 2, 41-49.

Ablan, G. L. \& Rosario, W. M., 1961. Teuthid fish for marine culture in the Philippines. Fish. Gaz. Philipp. 5, 23-24.

Bardach, J. E., Rhyter, J. H. \& MC LARneY, W. O., 1972. Aquaculture. Wiley-Interscience, London, $868 \mathrm{pp}$.

Ben-Tuvia, A., KissiL, G. W. \& Popper, D., 1973. Experiments in rearing rabbitfishes (Siganus rivulatus) in sea water. Aquaculture 1, 359-364.

Blanco, G. J. \& Villadolid, D. V., 1939. Fish fry industries of the Philippines. Philipp. J. Sci. 69, 69-98.

Cuvier, M. B. \& Valenctennes, M. A., 1835. Histoire naturelle des poissons. Levrault, Paris, $10,1-482$.

DAY, F., 1958. The fishes of India. Dawson, London 1, 1-778.

Delor, A., 1973. Elevage du bar americain. II. Solutions aux problèmes posés. Sci. Pêche 225, $1-20$.

Fowler, H. W., 1928. The fishes of Oceania. Mem. Bernine P. Bishop Mus. 10, 1-540.

FujTrA, S. \& UENO, M., 1954. On the development of the egg and prelarval stages of Siganus fuscescens (HoutTuYN) by artificial insemination. Jap. J. Ichthyol. 3, 129-132.

Herre, A. W. \& Montalban, H. R., 1928. The Philippine siganids. Philipp. J. Sci. 35, 151-185.

Herzberg, A., 1973. Toxicity of Siganus luridus (Rüppeld) on the Mediterranean coast of Israel. Aquaculture 2, 89-91.

KÄNDLER, R. \& TAN, E. O., 1965. Investigations on the osmoregulation in pelagic eggs of gadoid and flatfishes in the Baltic. Part I. Changes in volume and specific gravity at different salinities. Coun. Meet. int. Coun. Explor. Sea (C.M.-I.C.E.S.) 43, 1-5. 
Kopsch, F., 1901. Die Entstehung des Dottersackentoblasts und die Furchung bei Belone acus. Int. Mschr. Anat. Physiol. 18, 43-65.

Kupfrer, C., 1878. Die Entwicklung des Herings im Ei. Jber. Konm. wiss. Unters. dt. Meere, Kiel 1874-1876, 175-226.

LAM, T. J., 1974. Siganids: their biology and mariculture potential. Aquaculture 3, 325-354.

Manacop, P. R., 1937. The artificial fertilization of dangit, Amphacanthus oramin (Bloch \& Schneider). Philipp. J. Sci. 62, 229-237.

Marshall, T. C., 1964. Fishes of the Great Barrier Reef and coastal waters of Queensland. Angus \& Robertson, Sydney, 566 pp.

MAY, R. C., 1974. Effects of temperature and salinity on yolk utilization in Bairdiella icistia (JoRDAN \& GILbERT) (Pisces: Sciaenidae). J. exp. mar. Biol. Ecol. 16, 213-225.

- Popper, D, \& MCVEY, J. P., 1974. Rearing and larval development of Siganus canaliculatus (PARX) (Pisces: Siganidae). Micronesia 10, 285-298.

Munro, J. S. R., 1955. The marine and fresh water fishes of Ceylon. Halstead, Sydney, 351 pp.

NordaHL, J. R., 1970. The development and morphology of Kupffer's vesicle in the plaice, Pleuronectes platessa (L.) and in the cod Gadus morbua L. Sarsia 42, 41-62.

Oppenhermer, J. M., 1936. Processes of localization in developing Fundulus. J. exp. Zool. 73, 405-444.

Popper, D., Gordin, H. \& Kissiz, G. W., 1973. Fertilization and hatching of rabbitfish, Siganus rivulatus. Aquaculture 2, 37-44.

RANDALL, J. E., 1961. Overgrazing of algae by herbivorous marine fishes. Ecology 42, 812.

Rosenthat, H. \& Fonds, M., 1973. Biological observations during rearing experiments with the garfish Belone belone. Mar. Biol. 21, 203-218.

Smith, J. L., 1965. The sea fishes of southern Africa. Central News Agency, Johannesburg, $580 \mathrm{pp}$.

Sor, C. L. \& LAM, T. J., 1973. Induced breeding and early development of the rabbit-fish Siganus oramin (Schneider). Proc. Symp. Biol. Res. Nat. Dev. Singapore, 1973, 49-56.

Tsuda, R. T. \& Bryan, P. G., 1973. Food preferences of juvenile Siganus rostratus and S. spinus in Guam. Copeia 1973, 604-606.

- Bryan, P. G., Frtzgerald, W. J. \& Tobras, W. J., 1974. Juvenile-adult rearing of Siganus (Pisces: Siganidae) in Guam. S.P.C. 7. Techn. Meet. Fish. Nuku'Olofa, Tonga, 1974, 1-4 (mimeo).

VlLLALUz, D. K., 1953. Fish farming in The Philippines. Bookman Inc., Manila, 336 pp.

WeSTERNhagen, H. von, 1970. Erbrütung der Eier von Dorsch (Gadus morbua), Flunder (Pleuronectes flesus) und Scholle (Pleuronectes platessa) unter kombinerten Temperatur- und Salzgehaltsbedingungen. Helgoländer wiss. Meeresunters. 21, 21-102.

- 1973a. A preliminary study on the food preferences of Siganus concatenata (Cuvier \& Valenciennes). Philipp. Scient. 10, 61-73.

- 1973b. The natural food of the rabbitfishes Siganus oramin and S. striolata. Mar. Biol. 22, $367-370$.

- 1974a. Food preferences in cultured rabbitfishes (Siganidae). Aquaculture 3, 109-117.

- 1974b. Rearing Siganus striolata in a closed sea water system. Aquaculture 4,97-98.

WÜLKER, W., 1964. Bewegungsrhythmen im Teleostier-Ei (Zeitrafferfilmuntersuchungen). 1. Esox lucius, Salmo trutta, S. fontinalis, S. iridetus. Zool. Jb. (Anat. Ontogenie Tiere) 73, $1-35$.

First author's address: Dr. H. v. Westernhagen

Biologische Anstalt Helgoland (Zentrale)

D-2 Hamburg 50

Palmaille 9

Federal Republic of Germany 